\title{
Interclass Difference in Pneumonia Risk in COPD Patients Initiating Fixed Dose Inhaled Treatment Containing Extrafine Particle Beclometasone versus Fine Particle Fluticasone [Corrigendum]
}

Price DB, Henley W, Cançado JED, et al. Int J Chron Obstruct Pulmon Dis. 2022;17:355-370

On page 356, last paragraph of the Introduction section, the paragraph should be corrected from " ... Collectively, there is a requirement for a real- world study comparing the use of extrafine particle fixed dose combination beclometasone

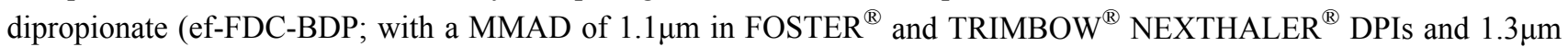
in FOSTER ${ }^{\circledR}$ pMDI) with other ICSs, such as fine particle fluticasone (fp-FDC-F; with a MMAD of $3.9 \mu \mathrm{m}$ and $3.2 \mu \mathrm{m}$ for propionate $\left(\right.$ SERETIDE $^{\circledR}$ DISKUS $^{\circledR}$ ) and furoate $\left(\right.$ RELVAR $^{\circledR}$ ELLIPTA $^{\circledR}$ ) esters respectively). ${ }^{21-23}$ to “ ...Collectively, there is a requirement for a real-world study comparing the use of extrafine particle fixed dose combination beclometasone dipropionate (ef-FDC-BDP; with a MMAD of $1.1 \mu \mathrm{m}$ in TRIMBOW ${ }^{\circledR}$ pMDI and $1.3 \mu \mathrm{m}$ in FOSTER ${ }^{\circledR}$ pMDI) with other ICSs, such as fine particle fluticasone (fp-FDC-F; with a MMAD of $3.9 \mu \mathrm{m}$ and $3.2 \mu \mathrm{m}$ for propionate (SERETIDE ${ }^{\circledR}$ DISKUS $^{\circledR}$ ) and furoate $\left(\operatorname{RELVAR}^{\circledR}\right.$ ELLIPTA $\left.^{\circledR}\right)$ esters respectively). ${ }^{21-23}$

The authors apologize for this error and advise they do not affect the results of the paper.

\section{Publish your work in this journal}

The International Journal of COPD is an international, peer-reviewed journal of therapeutics and pharmacology focusing on concise rapid reporting of clinical studies and reviews in COPD. Special focus is given to the pathophysiological processes underlying the disease, intervention programs, patient focused education, and self management protocols. This journal is indexed on PubMed Central, MedLine and CAS. The manuscript management system is completely online and includes a very quick and fair peer-review system, which is all easy to use. Visit http://www. dovepress.com/testimonials.php to read real quotes from published authors. 